\title{
Employer Perceptions Of Student Informational Interviewing Skills And Behaviors
}

\author{
Claudia Orr, Northern Michigan University, USA \\ Bruce Sherony, Northern Michigan University, USA \\ Carol Steinhaus, Northern Michigan University, USA
}

\begin{abstract}
Employers continue to report that soft skills are critically important in obtaining employment and achieving long-term career success. Given the challenging job market for college graduates, business school faculty need to provide practical opportunities for students to develop their soft skills in professional settings. A longitudinal study was conducted at a Midwestern university's AACSB accredited College of Business to determine the soft skills that employers believe students need to improve on to be successful. This paper shares 1) a management-oriented learning assignment that combines soft skill learning and application with professionals in work situations and 2) results of the professionals' perceptions of the students' soft skills. Results of this research will help faculty assess and improve their instructional methodology to better prepare students to meet employer expectations.
\end{abstract}

Keywords: Informational Interview; Soft Skills; Employer Perceptions; Professionalism; Business Curricula

\section{INTRODUCTION}

$\mathrm{t}$ is no surprise that the job market for college graduates is far from stellar. However, reports in 2011 are slightly more hopeful for job seekers than in the last few years. According to the latest projections by the National Association of Colleges and Employers (NACE), employers plan to hire 19.3 percent more new
graduates in 2010-2011 than they did in 2009-2010 (Job Outlook, 2011). Despite this glimmer of hope, graduates will continue to face extraordinary levels of competition in the job market given the 9.2 percent jobless rate in July 2011 (Employment Situation Summary, 2011).

As university business faculty, are we doing all we can to prepare our students with the skills employers expect from the extensive pool of candidates? Employers continue to report that soft skills are critically important in obtaining employment and achieving long-term career success. Students should be provided with opportunities to develop their soft skills in professional settings. Further, the literature supports the need to provide experiential opportunities to better equip students for the demands of the workplace. One way that students can be given both of these opportunities is through an informational interview assignment.

This paper first reviews the literature on the importance of soft skill training and experiential learning opportunities. Second, a management-oriented learning assignment is described that combines soft skill learning and application in a professional work situation. This assignment enables college business students to practice using soft skills. Finally, results of research are shared that identify professionals' perceptions of these students' soft skills.

\section{REVIEW OF LITERATURE}

Employers continually emphasize the importance of hiring individuals with well-developed soft skills. The NACE Job Outlook 2008 survey of 276 employers found that employers cited "communication skills, a strong work 
ethic, teamwork skills, initiative and interpersonal skills, in that order, as the top characteristics that they look for in new hires" (Di Meglio, 2008, para. 5). After interviewing more than 300 employers, Peter D. Hart Research Associates, Inc. (on behalf of The Association of American Colleges and Universities) found that teamwork, communication, and critical thinking skills were essential learning outcomes for college students (How Should Colleges . . . 2006). In fact, employers expressed great frustration "with the challenges of finding ' 360 degree people' who have both the specific job/technical skills and the broader skills (communication skills, teamwork skills, problem-solving skills, and work ethic) necessary to promise greater success for both the individual and their employer" (How Should Colleges . . ., 2006, pg. 7). According to Brett Good (2006), President of the Southern California District of Robert Half International Inc., "interpersonal abilities such as diplomacy, persuasiveness and effective face-to-face communication will remain vital" (p. 63). Although employers rate soft skills highest in importance for entry-level success in the workplace (Wilhelm, 2004), these skills are just as critical for promotion opportunities. For example, in a Robert Half International survey of chief financial officers, more than one-third said that other than technical skills and industry knowledge, the characteristic that impresses them most when interviewing executive-level candidates was verbal communication skills (Good, 2006).

Despite the importance of soft skills to employers, Mitchell, Skinner and White (2010) report that many employees in business are deficient in these skills. Specifically, Smith (2005) reports that management education has been criticized for being disconnected from practice. He explains that business schools focus too heavily on concepts and theories that do not pertain to practice and instead should do more to help students develop soft skills such as communication, teamwork and leadership (Smith, 2005). Doria, Rozanski and Cohen (2003) contend that even though social skills are difficult to teach, curricula can be designed to promote them. Elmuti (2004, p. 443) further supports these claims by stating, "Business schools nowadays teach mostly functions of business. They accept inexperienced people and provide them with analytical decision-making skills, while the demand is asking for more. Companies such as Alcan, BT, Fujitsu, Motorola, and the Royal Bank of Canada Financial Group are in need of managers not only possessing analytical decision-making skills, but also 'soft skills"'.

In response to the criticisms levied by employers on the lack of soft skill training, Mitchell, Skinner and White (2010) believe that research is needed in the area of soft skills so that improved instructional methodology may be developed and applied. This may have already begun at the post-baccalaureate level. According to Dvorak (2007), some schools are responding to employers' growing interest in soft skills. Many may be surprised to learn that MBA programs are the ones addressing this need. Dartmouth College's Tuck School of Business, Massachusetts Institute of Technology's Sloan School of Management, Stanford's Graduate School of Business, the University of Pennsylvania's Wharton School, the University of Virginia's Darden and Berkeley's Haas School are just a few of the programs that have recently begun focusing on topics such as teamwork, leadership, and communication - the "softer" side of management (Dvorak, 2007; Fisher, 2007). In fact, in response to recruiter feedback that graduates needed better leadership skills, the Massachusetts Institute of Technology's Sloan School of Management added classes and workshops on topics such as developing relationships and leading meetings (Dvorak, 2007).

While it is certainly encouraging that these high profile MBA programs are addressing the soft skills gap, integrating soft skill learning outcomes in the typical business classroom has proven to be challenging for a number of reasons. Traditional business school curricula focus largely on the "hard" functional areas of business. Course content is typically discipline-specific with little integration among subjects. Given resource allocation issues and philosophical issues, many business faculty oppose reducing core subjects to make room for soft skill learning (Navarro, 2008). Despite these barriers, there are proponents of integrating soft skills into the business curriculum, particularly, through experiential learning approaches (Bowers \& Metcalf, 2008; Cyphert, 2002; Elmuti, 2004; Luse, 1999; Li, Greenberg \& Nicholls, 2007; Navarro, 2008; Nodoushani \& Nodoushani, 1996).

Business leaders interviewed in the Peter Hart Research Associates, Inc. study reported that a major area of concern for both employers and recent college graduates is the degree to which college students are given the opportunity to put learning outcomes into practice. They insist that colleges give students more exposure to the business world through hands-on learning (How Should Colleges ..., 2006). 
Monks and Walsh (2001) also suggest that one restriction to management education is the fact that courses are taught as separate, distinct subject areas with little opportunity for integration of the material. In terms of soft skill preparation for future managers, Elmuti concludes, "it all comes down to the teacher" (2004, pg. 451). He emphasizes, "all teachers must constantly be changing and looking for better and more creative ways to teach management, especially when it comes to applying practical methods and 'soft' skills" (2004, pg. 451).

It is the theme of this paper that business graduates need to be concerned with professionalism, another area of soft skills. The term 'professional' is used among American businesspeople in two ways (Grove and Hallowell, 2002). One way is to refer to the types of work that require a high degree of knowledge, skill, and sound judgment. Certain occupations, such as lawyers and physicians, are seen as professional occupations. The other use of the term professional is to describe qualities of a person's behavior in work-related situations. Merriam-Webster's Dictionary (1997) defines professionalism as a "set of attitudes and behaviors believed to be appropriate to a particular occupation."

Appearance, body language and attitude are a major part of overall professionalism. In a study of 107 professional and administrative business people, Ashe and Nealy (2007) found that professionalism is important as it reflects the overall status of the firm. Polishing the areas of appearance, body language and attitude will help individuals excel in all aspects of their career. The assignment described in this paper is one small step toward preparing students with soft skills, including professionalism, and in closing the gap between 'classroom' and 'real world' experiences.

\section{INFORMATIONAL INTERVIEW ASSIGNMENT}

One of the researchers has been teaching a required undergraduate upper-level managerial communications course for business majors for over 10 years. An assignment was created specifically for the unit on interviewing that would address many of the skill gaps mentioned in the literature. In this communication course, the unit on interviewing focused on the manager's skills while conducting the interview. This process blends the informal conversation with a formal meeting (Beck, 1999). Murphy and Peck (1976) explain that business or professional persons will communicate orally not only within groups but also in an individual person-to-person basis and this work will at some time include interviewing and giving various instructions or demonstrations. Interviewing is a conversation with a purpose and uses all forms of communication - speaking, listening and writing (Murphy and Peck, 1976).

For this assignment, business students were given opportunities to further develop and apply soft skills in a practical environment where they could experience how the functional areas typically taught separately in academe, are integrated in business. This assignment gave these future businesspeople experience planning and conducting an informational interview.

Students learned about different types of interviews managers typically conduct, practiced writing different types of interview questions, and practiced planning informational interviews. The preparation phase is particularly important to the successful outcome of the conversation. Therefore, interviewers must prepare an interview as thoughtfully as if they were going to give a talk (Murphy and Peck, 1976, pg. 653). Specifically, students were required to identify preliminary information (defining interviewer and interviewee purposes) and planning the three phases of an informational interview: (1) opening; (2) question/response; and (3) summary/closing.

To practice managerial interviewing skills, each student (interviewer) was required to select (on their own) and make an appointment with a professional (interviewee) who held a position in a career field related to their major. The professional could not be a relative, friend or person with whom the student worked. Students were to find out as much about the professional's career field as possible including educational requirements, job descriptions, working conditions, communication needs, work experience, etc. Prior to the appointment, each student prepared and submitted a written informational interview plan. The instructor provided feedback on the written plan before the interviews were conducted. Students were prepared for possible deviations to their plans due to "in the moment" opportunities. They were able to ask different questions and take the conversation in a different direction, if necessary, to fulfill the purposes of their interview. Following the interviews, students gave oral presentations to the class. The entire class was then able to learn about each professional's career field. 
As Elmuti (2004, p. 443) says, "Learning becomes most powerful when it connects interesting ideas to lived experiences." This assignment was one method for connecting classroom work with the 'real world.' In other words, students practiced the role of a businessperson (interviewer) by applying appropriate soft skills.

\section{METHODOLOGY AND RESEARCH DESIGN}

The research study is an extension of the informational interview assignment in Managerial Communications, a required upper-level business course at a Midwestern university's AACSB accredited College of Business. During five semesters of the 2009-2011 academic years, a total of 196 students received the classroom instruction on managerial interviewing. Students were provided with three hours of in-class instruction that included the following:

- $\quad$ preliminary information (interviewer purposes, interviewee purposes, interviewee characteristics)

- $\quad$ opening (create rapport, provide orientation to interview, motivate interviewee)

- $\quad$ information getting and information giving (questions and details)

- $\quad$ closing (summarize and conclude)

All of the 196 students were then required to identify a professional that they would be able to interview during the semester. Four professionals were interviewed more than once throughout the study. A total of 178 different professionals were included in the research.

Each professional was sent a thank you letter from the researchers with a survey requesting that they evaluate the student interviewer's soft skills. The survey consisted of 13 statements, measured by 5 point Likert Scales that rated the student interviewer's skillfulness on opening the interview, adequately questioning and recording, acting professionally and closing the interview. The scale values assigned were 1 for strongly disagree and 5 for strongly agree. A self-addressed, stamped return envelope was enclosed for their convenience.

A total of 147 usable questionnaires were returned, achieving a 75 percent return rate. Chi-square tests were utilized to determine if any significant differences occurred in the response patterns among the five semesters. Differences were found in the observed versus the expectations for appropriate dress and being well groomed for the interview $\left(\chi^{2}=29.912, p<0.025\right)$. During one semester, student dress exceeded the interviewers' expectations and during another semester, student dress fell somewhat short of the interviewers' expectations. Men were expected to dress in shirts, ties, and dress pants. Women were expected to dress in skirts or dress pants and appropriate jewelry and accessories. No other differences were found among the remaining questions during the five semesters. The data was then used to analyze and interpret students' interview skills.

The purpose of this study is to determine the soft skills employers believe students need to improve on in order to be successful. It is hypothesized that achieving effective soft skills will lead to interviewer success. The following model summarizes this relationship. Results of this research will help faculty to assess and improve their instructional methodology to better prepare students to meet employer expectations.

\section{Proposed Model}

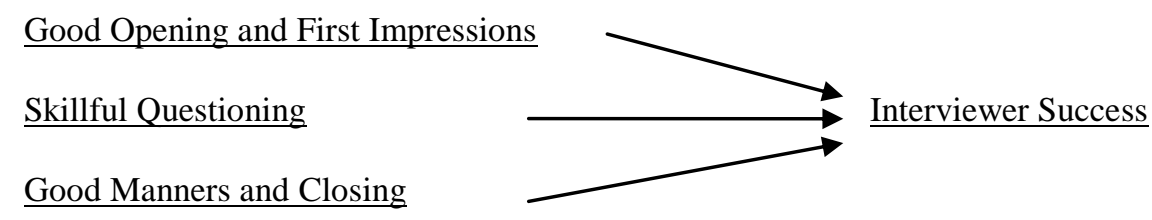

The following frequency distributions present a summary of statistical information resulting from the managerial responses. The data is presented from the strongest responses to the weakest responses. 


\section{Business Professionals' Perceived Interviewer Strengths}

Overall, the business professionals are very impressed with the student interviewers. The most impressive characteristics were the students' manners, preparation for the interview, positive attitude and ability to close the interview (Tables 1-4).

Table 1: Utilized Good Manners

\begin{tabular}{|l|c|c|c|c|}
\hline & Frequency & Percent & Valid Percent & Cumulative Percent \\
\hline Disagree & 1 & .7 & .7 & .7 \\
Agree & 32 & 21.8 & 21.9 & 22.6 \\
Strongly Agree & 113 & 76.9 & 77.4 & 100.0 \\
Total* $^{*}$ & 146 & 99.3 & 100.0 & \\
\hline
\end{tabular}

*Respondent Omission

Table 2: Came Prepared with a Pen, Paper and Questions

\begin{tabular}{|l|c|c|c|c|}
\hline & Frequency & Percent & Valid Percent & Cumulative Percent \\
\hline Disagree & 1 & .7 & .7 & .7 \\
Neutral & 2 & 1.4 & 1.4 & 2.0 \\
Agree & 29 & 19.7 & 19.7 & 21.8 \\
Strongly Agree & 115 & 78.2 & 78.2 & 100.0 \\
Total & 147 & 100.0 & 100.0 & \\
\hline
\end{tabular}

Table 3: Displayed a Positive Attitude

\begin{tabular}{|l|c|c|c|c|}
\hline & Frequency & Percent & Valid Percent & Cumulative Percent \\
\hline Neutral & 2 & 1.4 & 1.4 & 1.4 \\
Agree & 33 & 22.4 & 22.4 & 23.8 \\
Strongly Agree & 112 & 76.2 & 76.2 & 100.0 \\
Total & 147 & 100.0 & 100.0 & \\
\hline
\end{tabular}

Table 4: Effectively Closed the Interview

\begin{tabular}{|l|c|c|c|c|}
\hline & Frequency & Percent & Valid Percent & Cumulative Percent \\
\hline Neutral & 2 & 1.4 & 1.4 & 1.4 \\
Agree & 37 & 25.2 & 25.2 & 26.5 \\
Strongly Agree & 108 & 73.5 & 73.5 & 100.0 \\
Total & 147 & 100.0 & 100.0 & \\
\hline
\end{tabular}

Also rating very high were the interviewer's consideration of the business professional's time, clarity of purpose, appropriate introduction, and use of correct grammar (Tables 5-8).

Table 5: Was Considerate of Your Time and Circumstances

\begin{tabular}{|l|c|c|c|c|}
\hline & Frequency & Percent & Valid Percent & Cumulative Percent \\
\hline Neutral & 3 & 2 & 2 & 2 \\
Agree & 35 & 23.8 & 23.8 & 25.9 \\
Strongly Agree & 109 & 74.1 & 74.1 & 100.0 \\
Total & 147 & 100.0 & 100.0 & \\
\hline
\end{tabular}


Table 6: Clarity of Purpose, Accommodating and Politeness

\begin{tabular}{|l|c|c|c|c|}
\hline & Frequency & Percent & Valid Percent & Cumulative Percent \\
\hline Strongly Disagree & 1 & .7 & .7 & .7 \\
Disagree & 1 & .7 & .7 & 1.4 \\
Neutral & 2 & 1.4 & 1.4 & 2.7 \\
Agree & 49 & 33.3 & 33.3 & 36.1 \\
Strongly Agree & 94 & 63.9 & 63.9 & 100.0 \\
Total & 147 & 100.0 & 100.0 & \\
\hline
\end{tabular}

Table 7: Smiled, Introduced Themselves and Gave Firm Handshake

\begin{tabular}{|l|c|c|c|c|}
\hline & Frequency & Percent & Valid Percent & Cumulative Percent \\
\hline Neutral & 6 & 4.1 & 4.1 & 4.1 \\
Agree & 45 & 30.6 & 30.6 & 34.7 \\
Strongly Agree & 96 & 65.3 & 65.3 & 100.0 \\
Total & 147 & 100.0 & 100.0 & \\
\hline
\end{tabular}

Table 8: Used Correct Grammar and Professional Vocabulary

\begin{tabular}{|l|c|c|c|c|}
\hline & Frequency & Percent & Valid Percent & Cumulative Percent \\
\hline Disagree & 1 & .7 & .7 & .7 \\
Neutral & 4 & 2.7 & 2.7 & 3.4 \\
Agree & 48 & 32.7 & 32.7 & 36.1 \\
Strongly Agree & 94 & 63.9 & 63.9 & 100.0 \\
Total & 147 & 100.0 & 100.0 & \\
\hline
\end{tabular}

\section{Skills Needing Improvement}

The business professionals' ratings were positive on the characteristics of good posture, being well groomed and dressed appropriately, and demonstrating skill in questioning. However, students could improve on these characteristics. Tables 9-12 show these responses.

Table 9: Utilized Good Eye Contact, Posture, Expressions and Gestures

\begin{tabular}{|l|c|c|c|c|}
\hline & Frequency & Percent & Valid Percent & Cumulative Percent \\
\hline Disagree & 2 & 1.4 & 1.4 & 1.4 \\
Neutral & 10 & 6.8 & 6.8 & 8.2 \\
Agree & 57 & 38.8 & 39 & 47.3 \\
Strongly Agree & 77 & 52.4 & 52.7 & 100.0 \\
Total* $^{*}$ & 146 & 99.3 & 100.0 & \\
\hline
\end{tabular}

*Respondent Omission

Table 10: Asked Skilled, Well Thought-Out Questions

\begin{tabular}{|l|c|c|c|c|}
\hline & Frequency & Percent & Valid Percent & Cumulative Percent \\
\hline Disagree & 4 & 2.7 & 2.7 & 2.7 \\
Neutral & 7 & 4.8 & 4.8 & 7.5 \\
Agree & 63 & 42.9 & 42.9 & 50.3 \\
Strongly Agree & 73 & 49.7 & 49.7 & 100.0 \\
Total & 147 & 100.0 & 100.0 & \\
\hline
\end{tabular}


Table 11: Well Groomed and Dressed Appropriately for the Interview

\begin{tabular}{|l|c|c|c|c|}
\hline & Frequency & Percent & Valid Percent & Cumulative Percent \\
\hline Strongly Disagree & 5 & 3.4 & 3.4 & 3.4 \\
Disagree & 6 & 4.1 & 4.1 & 7.5 \\
Neutral & 10 & 6.8 & 6.8 & 14.4 \\
Agree & 40 & 27.2 & 27.4 & 41.8 \\
Strongly Agree & 85 & 57.8 & 58.2 & 100.0 \\
Total* & 146 & 99.3 & 100.0 & \\
\hline
\end{tabular}

*Respondent Omission

Table 12: Asked the Right Number of Questions

\begin{tabular}{|l|c|c|c|c|}
\hline & Frequency & Percent & Valid Percent & Cumulative Percent \\
\hline Disagree & 7 & 4.8 & 4.8 & 4.8 \\
Neutral & 6 & 4.1 & 4.1 & 8.8 \\
Agree & 71 & 48.3 & 48.3 & 57.1 \\
Strongly Agree & 63 & 42.9 & 42.9 & 100.0 \\
Total & 147 & 100.0 & 100.0 & \\
\hline
\end{tabular}

\section{Achieving Interviewer Success}

Approximately $61 \%$ of the responding business professionals strongly agree that the student interviewer would likely be an effective employee. Table 13 summarizes these results.

Table 13: Would be an Effective Employee

\begin{tabular}{|l|c|c|c|c|}
\hline & Frequency & Percent & Valid Percent & Cumulative Percent \\
\hline Disagree & 2 & 1.4 & 1.4 & 1.4 \\
Neutral & 5 & 3.4 & 3.4 & 4.8 \\
Agree & 48 & 32.7 & 33.1 & 37.9 \\
Strongly Agree & 90 & 61.2 & 62.1 & 100.0 \\
Total* & 145 & 98.6 & 100.0 & \\
\hline
\end{tabular}

*Respondent Omission

A multiple linear regression analysis using stepwise procedures was undertaken to highlight the most important criteria relating to the business professionals' responses of the student interviewer as being an effective employee. The skills of utilizing good eye contact, good posture, favorable facial expressions and good gestures were found to be very important for employee success. Displaying a positive attitude, being well groomed and dressing appropriately for the interview were also found to be very important. It was also found that asking skilled and well thought out questions are very important traits for student interviewers to master. Being considerate of the business professional's time and circumstances also related favorably with expected employee performance.

\section{DISCUSSION}

While the researchers caution that the results may not be generalizable beyond this study, several observations can be made from the frequency distribution results presented, the summary statistics in Table 14, and the qualitative comments that the business professionals included when evaluating the student interviewers. Business faculty can consider these results when preparing students to meet employer expectations.

The student interviewers made very positive impressions during these interviews. This probably results from the careful in-class training by the instructor on the techniques, skills and approaches to interviewing. The 12 
measures seemed to fulfill the responding business professionals' expectations for the professionalism skills needed to conduct an on the job interview. No other criterion was mentioned by the professionals as being important for successfully conducting an interview.

The responding business professionals rated students very high in certain skills. Ratings are strong for utilizing good manners, coming prepared, displaying a positive attitude, and closing the interview. Showing consideration of the business professionals' time, clearly stating the purpose, properly introducing themselves, and using correct grammar were also rated high.

The researchers believe that students need improvement in three distinct areas. First, making proper eye contact, using good posture, and using appropriate facial expressions and gestures were rated somewhat lower. Second, improvements are needed in developing skilled, well thought-out questions and asking the right number of questions. Third, being well groomed and appropriately dressed were areas also needing improvement. Based on the frequency response patterns and the descriptive statistics displayed in Table 14, the professionals rated students lower on these three skill areas and the variability of the ratings on these characteristics seems to increase. Overall findings support that these are important traits for interviewer success.

Table 14: Descriptive Statistics

\begin{tabular}{|l|c|c|c|c|c|c|}
\hline & N & Minimum & Maximum & Sum & Mean & $\begin{array}{c}\text { Std. } \\
\text { Deviation }\end{array}$ \\
\hline Utilized Good Manners & 146 & 2 & 5 & 695 & 4.76 & .474 \\
\hline $\begin{array}{l}\text { Came Prepared with a Pen, Paper and } \\
\text { Questions }\end{array}$ & 147 & 2 & 5 & 699 & 4.76 & .505 \\
\hline Displayed a Positive Attitude & 147 & 3 & 5 & 698 & 4.75 & .466 \\
\hline Effectively Closed the Interview & 147 & 3 & 5 & 694 & 4.72 & .479 \\
\hline $\begin{array}{l}\text { Was Considerate of your Time and } \\
\text { Circumstances }\end{array}$ & 147 & 3 & 5 & 694 & 4.72 & .494 \\
\hline $\begin{array}{l}\text { Clarity of Purpose, Accommodating and } \\
\text { Politeness }\end{array}$ & 147 & 1 & 5 & 675 & 4.59 & .628 \\
\hline $\begin{array}{l}\text { Smiled, Introduced Themselves and Gave a } \\
\text { Firm Handshake }\end{array}$ & 147 & 3 & 5 & 678 & 4.61 & .567 \\
\hline $\begin{array}{l}\text { Used Correct Grammar and Professional } \\
\text { Vocabulary }\end{array}$ & 147 & 2 & 5 & 676 & 4.60 & .581 \\
\hline Would be an Effective Employee & 145 & 2 & 5 & 661 & 4.56 & .633 \\
\hline $\begin{array}{l}\text { Utilized Good Eye Contact, Posture, } \\
\text { Expressions and Gestures }\end{array}$ & 146 & 2 & 5 & 647 & 4.43 & .684 \\
\hline Asked Skilled, Well Thought-Out Questions & 147 & 2 & 5 & 646 & 4.39 & .708 \\
\hline $\begin{array}{l}\text { Well Groomed and Dressed Appropriately for } \\
\text { the Interview }\end{array}$ & 146 & 1 & 5 & 632 & 4.33 & 1.011 \\
\hline Asked the Right Number of Questions & 147 & 2 & 5 & 631 & 4.29 & .760 \\
\hline
\end{tabular}

\section{CONCLUSION}

Today's students face enormous employment dislocations from job losses due to downsizing, mergers, acquisitions and cost cutting. The use of temporary employees, outsourcing, and electronic technology shifts positions and functions to various locations. Doing more with less is also a recurring theme as many states and institutions find their annual budgets strained. Further, competitive pressures cause many organizations to flatten their structures and become lean, which expands the range of job tasks and job complexity for today's graduates. Such dislocations often result in the lack of familiarity of contexts and the lack of people who provide role models in their lives. 
In order to obtain occupational positions and become successful, it is of utmost importance that student job seekers display professionalism when seeking and engaging in employment. The student job seekers' initial impressions, preparedness, appearance, attitude, questioning articulation, and closing are among the critical skills of professionalism. To the extent that such skills show compatibility with their supervisor's expectations and the norms and values of their company, industry and society, the student graduate will likely have a better chance of employment and career success.

Business school curricula should include training and learning about soft skills, including professionalism. The literature and business professional responses support the importance of professionalism for career success. Business school training in professionalism was demonstrated in student interviewer performance. Business professionals rated students positively when these skills were present. Business school faculty are encouraged to model and integrate these skills into their courses.

\section{AUTHOR INFORMATION}

Claudia Orr is a Professor of Management in the College of Business at Northern Michigan University. She earned her Ph.D. from the University of Minnesota. She teaches Communications and Training courses at the undergraduate and graduate levels. E-mail: corr@nmu.edu

Bruce Sherony is a Professor of Management in the College of Business at Northern Michigan University. He earned his Ph.D. from St. Louis University. He teaches courses in Strategic Management, Small Business and Entrepreneurship. E-mail: bsherony@nmu.edu

Carol Steinhaus is an Associate Professor of Management in the College of Business at Northern Michigan University. She earned her Ph.D. from University of Nebraska-Lincoln. She teaches courses in Organizational Behavior and Human Resources and is passionately involved in study abroad opportunities for students. E-mail: csteinha@nmu.edu

\section{REFERENCES}

1. Ashe, C. \& Nealy, C. (2007). Business etiquette: New day, new time. Proceedings of the 2007 Association for Business Communication Annual Convention.

2. Beck, C.E. (1999). Managerial Communication: Bridging Theory and Practice. Upper Saddle River, NJ: Prentice Hall.

3. Bowers, M.Y. \& Metcalf, M.A. (2008). What employers want and what students need: Integrating business communication into undergraduate and graduate business courses. Proceedings of the 2008 Association for Business Communication Annual Convention.

4. Cyphert, D. (2002). Integrating communication across the MBA curriculum. Business Communication Quarterly, 65(3), 81-86.

5. Di Meglio, F. (2008, February 21). A transcript for soft skills. Retrieved June 28, 2010, from http://www.businessweek.com/bschools/content/feb2008/bs20080221_706663.htm

6. Doria, J. Rozanski, H., \& Cohen, E. (2003, Fall). What business needs from business schools. Retrieved July 5, 2010, from http://www.strategy-business.com/article/03305?gko=527bd

7. Dvorak, P. (2007, February 12). MBA programs hone 'soft skills'. Retrieved June 28, 2010, from http://online.wsj.com/article/SB117124443482305364.html

8. Elmuti, D. (2004). Can management be taught?: If so, what should management education curricula include and how should the process be approached? Management Decision, 42(3/4), 439-453.

9. Employment Situation Summary (2011, July 8). Retrieved July 14, 2011, from http://www.bls.gov/news.release/empsit.nr0.htm

10. Fisher, A. (2007, April 23). The trouble with MBAs. Retrieved June 28, 2010, from http://money.cnn.com/magazines/fortune/fortune_archive/2007/04/30/8405397/index.htm

11. Good, B. (2006, June). What tomorrow's candidates need to know today. Business Credit, 108(6), 63. 
12. Grove, C. \& Hallowell, W. (2002). The seven balancing acts of professional behavior in the United States: A cultural values perspective. Retrieved July 19, 2010, from http://www.grovewell.com/pub-usaprofessional.html

13. How should colleges prepare students to succeed in today's global economy? (2006, December 28). Retrieved July 5, 2010, from http://www.aacu.org/leap/documents/Re8097abcombined.pdf

14. Job Outlook 2011 Spring Update (2011, Spring). Retrieved July 14, 2011, from http://www.naceweb.org/Research/Job_Outlook/Job_Outlook.aspx?referal=research\&menuID=69

15. Li, T., Greenberg, B., \& Nicholls, J. (2007). Teaching experiential learning: Adoption of an innovative course in an MBA marketing curriculum. Journal of Marketing Education, 29(1), 25-33.

16. Luse, D. (1999). Incorporating business communication in an integrative business seminar. Business Communication Quarterly, 62(1), 96-100.

17. Merriam-Webster's Collegiate Dictionary. (1997). $10^{\text {th }}$ ed. Springfield, MA: Merriam-Webster, Inc.

18. Mitchell, G.W., Skinner, L.B., \& White, B.J. (2010, Winter). Essential soft skills for success in the twentyfirst century workforce as perceived by business educators. The Delta Pi Epsilon Journal, LII(1), 43-53.

19. Monks, K. \& Walsh, J.S. (2001). The role of postgraduate education in management development. Journal of European Industrial Training, 25(2-4), 148.

20. Murphy, H. A. \& Peck, C. E. (1976). Effective Business Communications. New York: McGraw-Hill, Inc.

21. Navarro, P. (2008). The MBA core curricula of top-ranked U.S. business schools: A study in failure? Academy of Management Learning \& Education, 7(1), 108-123.

22. Nodoushani, O \& Nodoushani, P. (1996). Rethinking the future of management education. Human Systems Management, 15(3), 173-181.

23. Smith, G. (2005). Problem-based learning: Can it improve managerial thinking? Journal of Management Education, 29(2), 357-378.

24. Wilhelm, W J. (2004, Spring/Summer). Determinants of moral reasoning: Academic factors, gender, richness of life experiences, and religious preferences. The Delta Pi Epsilon Journal, XLVI(2), 105-121. 